\title{
PENGEMBANGAN MEDIA $E$-LEARNING BERBASIS WEB DENGAN PENDEKATAN CONTEXTUAL TEACHING AND LEARNING (CTL) UNTUK MENINGKATKAN BELAJAR MANDIRI MAHASISWA
}

\author{
Revi Gina Gunawan ${ }^{1, a)}$, Betty Zelda Siahaan², b) , I Made Astra ${ }^{3, \text { b) }}$ \\ Prodi Pendidikan Fisika FMIPA UNJ Program Magister Pendidikan \\ Fisika, Jl. Pemuda No 10, Jakarta13220. \\ Email: a)revi.gina.gunawan@gmail.com
}

\begin{abstract}
Abstrak
Penelitian ini bertujuan untuk mengembangkan media E-Learning berbasis Web dengan pendekatan Contextual Teaching and Learning (CTL) untuk meningkatkan belajar mandiri mahasiswa pada mata kuliah Fisika Dasar Layanan bagi mahasiswa S1. Metode penelitian yang digunakan pada penelitian ini adalah Research and Development $(R \& D)$ menggunakan model ADDIE (Analyze - Design - Develop Implementation - Evaluation). Instrumen yang digunakan dalam penelitian ini berupa kuisioner. Uji kelayakan e-learning dilakukan oleh para ahli untuk media, materi dan pembelajaran, serta oleh pengguna. Hasil dari ahli media yaitu $86,1 \%$, ahli materi $84,7 \%$, ahli pembelajaran $87,9 \%$ dan hasil ujicoba pada pengguna didapat $85,7 \%$. Dapat disimpulkan bahwa media e-learning berbasis Web dengan pendekatan Contextual Teaching and Learning (CTL) dapat digunakan sebagai media pembelajaran. Untuk menguji keefektifan media dalam meningkatkan belajar mandiri kemudian implementasi dilakukan pada kelas eksperimen, mahasiswa diberi kuisioner yang telah melalui uji validasi ahli dan empiris dan diperoleh nilai $\mathrm{N}$-Gain sebesar 0,6. Dapat disimpulkan bahwa secara keseluruhan Media e-learning berbasis web dapat meningkatkan belajar mandiri mahasiswa.
\end{abstract}

Kata-kata kunci: Media E-Learning, Contextual Teaching and Learning (CTL), Belajar Mandiri.

\begin{abstract}
This research aims to develop Web-based E-Learning media with Contextual Teaching and Learning (CTL) approach to improve self directed learning in Basic Physics course for undergraduate students. Method used in this research is Research and Development ( $R$ \& D) using model of ADDIE (Analyze Design - Develop - Implementation - Evaluation). The instrument used in this study is a questionnaire. The e-learning feasibility test is undertaken by media expert, materials and learning, as well as by users. The result of media expert is $86,1 \%$, material expert $84,7 \%$, learning expert $87,9 \%$ and result of user test obtained $85,7 \%$. It can be concluded that Web-based e-learning media with Contextual Teaching and Learning (CTL) approach can be used as a learning media. To test the effectiveness of media in improving self-study then implementation is done in experiment class, students are given questionnaires that have been through expert and empirical validation test and obtained $\mathrm{N}$-Gain value of 0.6 . It can be concluded that overall Web-based e-learning media can improve self directed learning.
\end{abstract}

Keywords: E-Learning Media, Contextual Teaching and Learning (CTL), Self Directed Learning 


\section{PENDAHULUAN}

Perkembangan dunia abad 21 ditandai dengan pemanfaatan teknologi informasi dan komunikasi dalam segala segi kehidupan, termasuk dalam proses pembelajaran. Dunia kerja menuntut perubahan kompetensi. Kemampuan berpikir kritis, memecahkan masalah, dan berkolaborasi menjadi kompetensi penting dalam memasuki kehidupan abad 21. Sekolah dituntut mampu menyiapkan siswa memasuki abad 21. Abad 21 menuntut penguasaan berpikir tingkat tinggi, berpikir kritis, menguasai teknologi informasi, mampu berkolaborasi, dan komunikatif.

Perkembangan internet yang mendunia menuntut pendidik untuk mampu memanfaatkan teknologi tersebut dalam proses pembelajaran, salah satunya adalah pemanfaatan platform learning management system untuk membangun sebuah e-learning (pembelajaran elektronik) yang didalamnya pendidik dapat mendesain pembelajaran sesuai dengan tujuan yang ingin dicapai. $E-$ learning dalam dunia pendidikan keberadaannya tidak dapat dipisahkan dengan tuntutan pembelajaran abad 21. Dalam perspektif pendidikan global, e-learning dapat merupakan penopang efektifitasnya penyelenggaraan pendidikan. E-learning diharapkan dapat mewujudkan pembelajaran yang menarik dan interaktif serta dapat digunakan secara mandiri oleh peserta didik dimana saja dan kapan saja.

Hasil analisis kebutuhan untuk mahasiswa, dari 181 responden pada perguruan tinggi di Kota Sungai Penuh Propinsi Jambi yaitu Institut Agama Islam Negeri (IAIN) Kerinci dan Sekolah Tinggi Keguruan dan Ilmu Pendidikan (STKIP) Muhammadiyah Wilayah Jambi pada Oktober 2016, menunjukkan bahwa perkuliahan fisika dasar saat ini belum optimal karena minimnya media sebagai sumber belajar. 92,8\% Proses perkuliahan fisika dasar masih berpusat pada dosen (teacher centered), 88,7\% Dalam pembelajaran mahasiswa hanya mendengarkan, mencatat dan mengulang kembali, hampir 90\% Dosen menjelaskan dengan menggunakan buku referensi dan modul saja dalam pembelajaran, padahal 90,6\% mahasiswa dari 181 responden menyatakan lebih tertarik belajar fisika dasar dengan media pembelajaran (animasi, simulasi, video, dll), 98,3\% mahasiswa juga menyatakan akan lebih antusias dalam proses pembelajaran dengan menggunakan media pembelajaran, $85,6 \%$ mahasiswa juga menyatakan belum tersedianya media pembelajaran online mandiri terintegrasi (e-learning) yang dapat digunakan dalam pembelajaran. Seharusnya dengan pemanfaatan internet mahasiswa dapat difasilitasi dengan media e-learning yang dapat diakses secara fleksibel tidak terbatas ruang dan waktu atau dapat digunakan secara mandiri untuk mendukung perkuliahan. Institut Agama Islam Negeri (IAIN) Kerinci juga sudah dilengkapi dengan fasilitas hotspot. Namun, fasilitas ini belum dimanfaatkan secara maksimal oleh mahasiswa untuk dijadikan salah satu sumber belajar, sehingga fasilitas ini tidak termanfaatkan dengan optimal.

Hasil analisis kebutuhan untuk dosen pengampu fisika dasar dari perguruan tinggi di Kota Sungai Penuh Propinsi Jambi yaitu Institut Agama Islam Negeri (IAIN) Kerinci dan Sekolah Tinggi Keguruan dan Ilmu Pendidikan (STKIP) Muhammadiyah Wilayah Jambi yang terdiri dari 7 responden, menunjukkan bahwa belum tersedianya media e-learning untuk fisika dasar, metode pembelajaran yang mendominasi perkuliahan yaitu ceramah dan diskusi, $100 \%$ menyatakan $e$ learning dipandang dapat menunjang proses pembelajaran fisika dan pengembangan media $e$ learning untuk fisika dasar dibutuhkan.

Hasil observasi ke Pusat Teknologi dan Komunikasi Kementerian pendidikan dan kebudayaan (Pustekom kemdikbud) Ciputat pada tanggal 15 November 2016 dimana media e-learning yang dikembangkan disana adalah untuk jenjang paud hingga Sekolah Menengah yaitu Rumah Belajar dengan situs resminya http://belajar.kemdikbud.go.id, sedangkan untuk perguruan tinggi saat ini belum ada.

Berdasarkan latar belakang yang telah dipaparkan di atas, maka pada penelitian ini dikembangkan Media E-Learning Berbasis Web untuk mendukung perkuliahan Fisika Dasar Layanan dengan Pendekatan Contextual Teaching And Learning (CTL) dan diharapkan dapat meningkatkan belajar mandiri mahasiswa melalui media yang dikembangkan. 


\section{METODE}

Metode penelitian yang digunakan pada penelitian ini adalah metode penelitian dan pengembangan atau dikenal Research and Development $(R \& D)$. Penelitian pengembangan adalah penelitian yang tertuju pada proses untuk menghasilkan objek yang dapat dilihat atau diraba. Model pengembangan yang digunakan adalah model ADDIE.

Model ADDIE merupakan salah satu pendekatan desain sistem pembelajaran yang dapat diimplementasikan untuk mendesain dan mengembangkan program pelatihan yang efektif dan efisien. Tahap-tahap kegiatan yang terdapat dalam model ADDIE terdiri dari: Analysis (menganalisis), Design (merancang), Development (mengembangkan), Implementation (mengimplementasikan), dan Evaluation (mengevaluasi). Selain menguji kelayakan media dalam penelitian ini juga menguji keefektifan media pada uji lapangan.

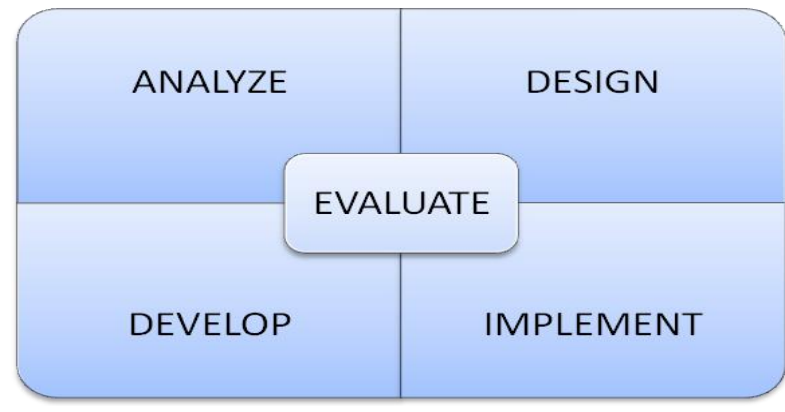

Gambar 1. Model ADDIE

\section{HASIL DAN PEMBAHASAN}

Hasil pengembangan yang telah dilakukan menghasilkan produk berupa media e-learning berbasis web dengan pendekatan contextual teaching and learning (CTL) pada mata kuliah Fisika Dasar Layanan. Sasaran pengguna media adalah mahasiswa Program Studi Tadris Matematika Fakultas Tarbiyah Institut Agama Islam Negeri (IAIN) Kerinci. Media e-learning dikemas dalam bentuk web dengan alamat http://elearningrevi.com/revilearning/index.php

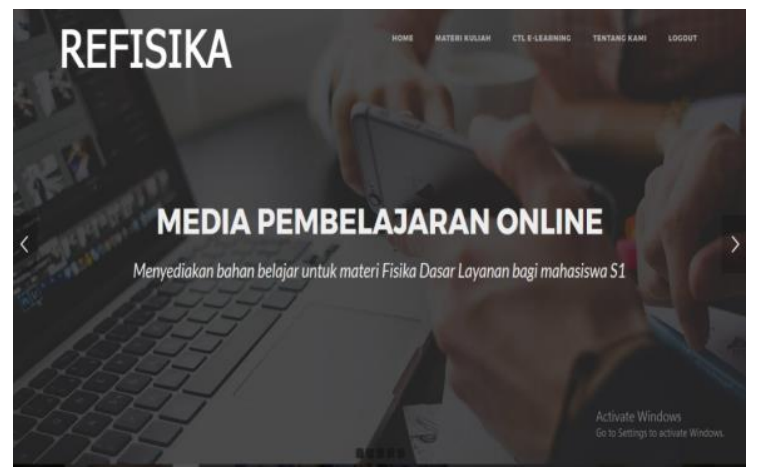

Gambar 2. Tampilan Media E-Learning

Kelayakan media E-Learning berbasis web diperoleh dari hasil validasi ahli dan uji empiris pada mahasiswa. Media e-learning berbasis web yang dikembangkan divalidasi oleh ahli materi, ahli media dan ahli pembelajaran. Hasil penilaian tersebut kemudian dijadikan sebagai bahan revisi untuk perbaikan media agar layak diproduksi sebagai media pembelajaran.

Data yang diperoleh adalah sebagai berikut: 
TABEL 1. Hasil Validasi Ahli Media

\begin{tabular}{lll}
\hline Aspek Penilaian & \% Skor Rata-rata & Interpretasi \\
\hline Kesesuaian Tujuan & $86,30 \%$ & Sangat baik \\
Aksessibilitas & $86,70 \%$ & Sangat baik \\
Interaktivitas & $86 \%$ & Sangat baik \\
Mutu Teknis/Penyajian & $86 \%$ & Sangat baik \\
Skor Rata-rata & $86 \%$ & Sangat baik \\
Keseluruhan & & \\
\hline
\end{tabular}

TABEL 2. Hasil Validasi Ahli Pembelajaran

\begin{tabular}{lll}
\hline Aspek Penilaian & \% Skor Rata-rata & Rata-rata Total \\
\hline Keefektifan & $83,7 \%$ & \\
Komunikasi & $87,5 \%$ & $83,6 \%$ \\
Aksessibilitas & $80 \%$ & \\
Kepuasaan Pengguna & $83,3 \%$ & \\
\hline
\end{tabular}

Uji coba kelompok kecil bertujuan untuk memperoleh informasi dari responden untuk perbaikan media e-learning yang dikembangkan. Uji coba kelompok kecil dilakukan pada 10 orang mahasiswa Fakultas Tarbiyah IAIN Kerinci. Responden diperkenalkan media e-learning yang dikembangkan dan kemudian responden mengisi kuisioner yang telah disediakan. Dari uji coba kelompok kecil diperoleh data sebagai berikut:

TABEL 3. Hasil Validasi Ahli Pembelajaran

\begin{tabular}{lll}
\hline Aspek Penilaian & \% Skor Rata-rata & Rata-rata Total \\
\hline Aksessibilitas & $83 \%$ & \\
Mutu Teknis / Penyajian & $74 \%$ & $80 \%$ \\
Keefektifan & $84 \%$ & \\
\hline
\end{tabular}

Untuk memperoleh data keefektifan media e-learning berbasis web dengan pendekatan contextual teaching and learning $(C T L)$ dalam meningkatkan belajar mandiri mahasiswa, maka dilakukan tes awal (pretest) dan tes akhir (postest) menggunakan instrumen belajar mandiri berupa kuisioner yang bertujuan untuk mengetahui sejauh mana produk yang dikembangkan dapat meningkatkan belajar mandiri mahasiswa. Sebelum instrumen belajar mandiri digunakan, instrumen tersebut di uji validitasnya secara empiris terlebih dahulu pada mahasiswa tarbiyah IAIN Kerinci.

Media e-learning berbasis web yang dikembangkan telah melewati beberapa tahap untuk dinyatakan layak diproduksi sebagai media pembelajaran fisika melalui berbagai revisi yang telah dilakukan. Keunggulan dari media e-learning berbasis web yang dikembangkan ini adalah dapat menjadi solusi bagi mahasiswa untuk mencari sumber belajar di luar waktu perkuliahan serta $e$ learning menggunakan pendekatan contextual teaching and learning sehingga lebih memudahkan mahasiswa untuk memahami materi fisika dengan menghubungkannya pada kehidupan sehari-hari sehingga pembelajaran menjadi lebih bermakna. 
Dari hasil evaluasi dengan penilaian yang diberikan oleh para ahli dan pengguna diperoleh ratarata persentase untuk ahli media yaitu $86,1 \%$, ahli materi $84,7 \%$, ahli pembelajaran $83,6 \%$ dan hasil uji coba kelompok kecil dengan persentase $83,3 \%$. Secara keseluruhan dapat diinterpretasikan dalam kategori sangat baik.

Aspek-aspek yang dikembangkan dalam penelitian ini antara lain yaitu kesesuaian tujuan, aksessibilitas, interaktivitas, mutu teknis/penyajian, isi/cakupan materi, kebahasaan, keefektifan (effectiveness), komunikasi (Communication), dan kepuasan pengguna (satisfaction). Aspek-aspek inilah yang kemudian menjadi indikator dari kualitas pengembangan produk yang dihasilkan. Dari hasil yang diperoleh untuk tiap aspek tersebut kita dapat menyatakan bahwa media e-learning layak digunakan sebagai media pembelajaran fisika.

Kelebihan dari e-learning berbasis web yang dikembangkan ini dibandingkan dengan penelitian sebelumnya yaitu menggunakan pendekatan contextual teaching and learning (CTL) dalam proses pembelajarannya, sehingga pembelajaran di dalam e-learning lebih terstruktur dan pengguna bisa diarahkan dengan langkah-langkah dari pendekatan tersebut untuk menemukan makna dari setiap pembelajaran yang diikuti. Penelitian-penelitian terdahulu cenderung mengedepankan aplikasi atau teknologi yang digunakan dalam mengembangkan e-learning. Dalam penelitian ini justru kontenlah yang menjadi fokus pengembangan yakni bagaimana konten dan kemudian keseluruhan dari bagian e-learning dapat memenuhi fungsi tenaga pendidik sebagai motivator dan fasilitator dalam pembelajaran.

Keefektifan dari media e-learning yang dikembangkan diujicobakan pada kelas eksperimen untuk melihat kemampuan media e-learning untuk meningkatkan belajar mandiri mahasiswa di luar jam perkuliahan menggunakan instrumen kuisioner belajar mandiri. Dari hasil tes awal dan tes akhir diperoleh nilai $\mathrm{N}$-Gain sebesar 0,6 yang dikategorikan sedang. Berdasarkan nilai tersebut maka dapat disimpulkan bahwa media e-learning dapat meningkatkan belajar mandiri mahasiswa.

Hal ini sejalan dengan hasil penelitian sebelumnya yang menyimpulkan bahwa disiplin diri memiliki dampak positif pada hasil belajar (Gurunovs, Kapenieks, Cakula, 2016). Berikutnya Husein juga menyimpulkan dalam penelitiannya bahwa sikap adalah prediktor signifikan terhadap niat peserta didik untuk menggunakan e-learning (Hussein,2016). Disiplin diri dan sikap merupakan bagian dari aspek belajar mandiri yang menunjukkan keterkaitan antara media e-learning dengan belajar mandiri dalam hal ini untuk mahasiswa sehingga keterukuran efektifitas dari $e$-learning dapat dilihat dari peningkatan belajar mandiri setelah menggunakan e-learning ini dalam pembelajaran

Hasil dari keseluruhan proses dalam penelitian ini menunjukkan bahwa media e-learning berbasis web sudah saatnya dikembangkan lebih lanjut dan lebih banyak lagi untuk memfasilitasi pembelajaran fisika di luar waktu perkuliahan karena hal ini sangat dibutuhkan.

\section{PENUTUP}

Berdasarkan hasil penelitian yang telah dilaksanakan maka diperoleh kesimpulan bahwa media elearning berbasis web dengan pendekatan Contextual Teaching and Learning (CTL) dapat digunakan sebagai alternatif pembelajaran di luar waktu perkuliahan serta dapat meningkatkan belajar mandiri mahasiswa.

\section{UCAPAN TERIMAKASIH}

Terima kasih saya ucapkan kepada dosen pembimbing dan semua pihak yang telah membantu terselesaikannya penelitian ini.

\section{REFERENSI}

[1] Adelheid, Andrea. 2015. Website No.1. Yogyakarta: MediaKom.

[2] Al-Tabany, Trianto Ibnu Badar. 2015. Mendesain Model Pembelajaran Inovatif, Progresif, dan Kontekstual. Jakarta: Prenadamedia Group. 
[3] Arsyad, Azhar. 2016. Media Pembelajaran. Jakarta: Rajagrafindo Persada.

[4] Asyar, Rayandra. 2011. Kreatif Mengembangkan Media Pembelajaran. Jakarta: Gaung Persada Press.

[5] Darmawan, Deni. 2014. Pengembangan E-Learning Teori dan Desain. Bandung: PT. Remaja Rosdakarya.

[6] Daryanto, Drs. 2016. Panduan Proses Pembelajaran Kreatif dan Inovatif. Jakarta: Publisher.

[7] Djamarah, Syaiful Bahri dan Aswan Zain. 2014. Strategi Belajar Mengajar. Jakarta: Rineka Cipta.

[8] Garrison, D. Randy. 2011. E-Learning in the 21st century: A framework for research and practice. NewYork : Routledge

[9] Giancoli. 2014. FISIKA: Prinsip dan Aplikasi. Jakarta: Erlangga

[10] Gooren-seiber, Stefanie. 2014. Information Management For Digital Learners. German : University of Bamberg Press $\backslash$

[11] Halliday, Resnick. 1985. Fisika Edisi ke 3 Jilid 1. Jakarta: Erlangga

[12] Halliday, Resnick. 1996. Fisika Edisi ke 3 Jilid 2. Jakarta: Erlangga

[13] Hirose, Lonngren. Introduction To Wave Phenomena. A Wiley Interscience Publication

[14] Hosnan. 2014. Pendekatan Saintifik dan Kontekstual dalam Pembelajaran Abad 21. Bogor: Ghalia Indonesia.

[15] Kadir, Abdul. 2014, Pengenalan Sistem Informasi, Yogyakarta: Andi Ofset.

[16] Komalasari, Kokom. 2014. Pembelajaran Kontekstual Konsep dan Aplikasi. Bandung: PT Refika Aditama.

[17] Loeksmanto, Waloejo. 1993. Medan Elektromagnet. Proyek Pembinaan Tenaga Kependidikan Pendidikan Tinggi.

[18] Mudjiman, Haris. 2011. Belajar Mandiri. Surakarta: UNS Press.

[19] Mundilarto, dkk. 1993. Fisika Dasar II. Jakarta: Proyek Penataran Guru

[20] Munir. 2012. Pembelajaran Jarak Jauh. Bandung: Alfabeta.

[21] Murdaka, Kuntoro. 2013. Fisika Dasar Edisi 2 untuk Mahasiswa Ilmu-Ilmu Eksakta, Teknik \& Kedokteran. Yogyakarta: Andi Offset

[22] Musfiqon. 2015. Pengembangan Media \& Sumber Pembelajaran. Jakarta: PT. Prestasi Pustakaraya.

[23] Olaniran, Bolani. 2009. Cases on Successful e-learning Practice in the Develop and Developing. USA: IGI Global

[24] Prawiradilaga, Dewi S,. 2012. Wawasan Teknologi Pendidikan. Jakarta: Kencana.

[25] Pribadi, Benny A. 2014. Desain dan Pengembangan Program Pelatihan Berbasis Kompetensi. Jakarta: Prenada Media Group.

[26] Rozi, Zaenal A. 2016. Modern Web Design. Jakarta: PT. Elex Media Komputindo.

[27] Rusman. 2012. Belajar dan Pembelajaran Berbasis Komputer. Bandung: Alfabeta.

[28] Sanjaya, Wina. 2011. Penelitian Pendidikan Jenis, Metode dan Prosedur. Jakarta: Prenada Media Group 
[29] Sears, Salinger. 1986. Thermodynamics, Kinetic Theory, and Statistical Thermodynamic Third Edition. USA: Addison Wesley Publishing Company

[30] Sears, Zemansky. 1994. Fisika untuk Universitas 3 Optika \& Fisika Modern. Bandung: Binacipta

[31] Sears, Zemansky. 1999. Fisika untuk Universitas 1 Mekanik Panas Bunyi. Jakarta: Trimitra Mandiri

[32] Smaldino, Lowther dan Russel. 2009. Teknologi Pembelajaran Dan Media Untuk Belajar Jakarta: Kencana.

[33] Sugiyono. 2016. Metode Penelitian Pendidikan: Pendekatan Kuantitatif, Kualitatif, dan $R \& D$. Bandung: Alfabeta.

[34] Suharsimi, Arikunto. 2012. Dasar-Dasar Evaluasi Pendidikan. Jakarta: Bumi Aksara.

[35] Sukmadinata, N. S. 2011. Metode Penelitian Pendidikan. Bandung: Rosda Karya.

[36] Tung, Khoe Yao. 2016. Desain Instruksional Perbandingan Model \& Implementasinya. Yogyakarta: Andi.

[37] Wahyuningsih, Makmur. 2017. E-Learning Teori dan Aplikasi. Bandung: Informatika.

[38] Wikipedia. 2016. Pembelajaran Elektronik. https://id.wikipedia.org/wiki/Pembelajaran elektronik (diakses 2016). 
